кандидат педагогічних наук, докторант

(Житомирський державний університет імені Івана Франка) samoilenckooxana@gmail.com ORCID: 0000-0002-2305-4111

\title{
СТАНОВЛЕННЯ СИСТЕМИ ОСВІТИ ДОРОСЛИХ У СЛОВАЦЬКІЙ РЕСПУБЛІЦІ НА ПОЧАТКУ ХХ СТОЛІТТЯ
}

\begin{abstract}
У статті представлено результати теоретичного аналізу особливостей становлення та розвитку системи освіти дорослих у Словацькій республіці на початку ХХ століття. Доведено виникнення у цеей період необхідності підвищення професійного, культурного та загального рівня освіти працівників; поглиблення та розширення їх компетентностей та професійної переорієнтації. Розкрито роль просвітницьких інституцій (народних шкіл та університетів, національного інституту словацької культури (Matice slovenskej) та ін.) у формуванні конщепції цุіложиттєвого навчання.
\end{abstract}

Ключові слова: освіта дорослих, народні школи та університети, ціложиттєве навчання, просвітницькі установи.

Постановка проблеми у загальному вигляді та ї̈ зв'язок із важливими науковими і практичними завданнями. Процес соціалізації не закінчується після досягнення людиною якогось певного віку, він безперервний. Тому освіта дорослих в усі історичні періоди вважалася найважливішою соціально-педагогічної функцією суспільства. Сучасна освітня система чутливо реагує на потреби населення у знанні, інформації, навчанні та розвитку, розширюючи ринок освітніх послуг, наповнюючи його новим змістом. У зв'язку з цим важливо звернутися до історії становлення освіти дорослих та розглянути її особливості у різні історичні періоди.

Переважна більшість європейських країн мають нормативні акти щодо законодавчого регулювання освіти дорослих, де визначено іiі цілі освіти, принципи й механізми державної підтримки, основні суб'єкти, їх права і обов'язки, способи координації між різними провайдерами освітніх послуг, а також принципи та схеми отримання коштів з бюджету. Так, за даними Global report on adult learning and education кількість дорослих, які навчаються в системі формальної й позаформальної освіти у першому десятилітті XXI ст. в країнах Свросоюзу перевищувала 37 \%. Зокрема, у Словаччині цей показник становить від 20 до $35 \%$. В Україні загальна кількість дорослих, які навчаються, становить менше $20 \%$. У цьому контексті вивчення досвіду Словацької Республіки з розбудови системи освіти дорослих викликає значний інтерес і може стати підгрунтям до творчого використання його позитивних ідей на українському грунті.

Аналіз основних досліджень і публікацій із зазначеної проблеми. У контексті дослідження важливими є праці вітчизняних і зарубіжних учених із проблем освіти дорослих в Україні: тенденції розвитку транснаціональної вищої освіти у розвинених країнах (Н. Авшенюк, Н. Пазюра, О. Проценко, А. Роляк, О. Сергєєва, М. Сорока); генезис пріоритетних тенденцій розвитку освіти дорослих в Україні (Л. Вовк, І. Литовченко, Л. Лук’янова, О. Мартіросян, С. Поточни, Л. Тимчук, Л. Шинкаренко) ; соціально-педагогічні аспекти різних категорій дорослих (Л. Горбунова, Н. Ничкало, І. Соколова, О. Фольварочний).

Предметом аналізу науковців виступав широкий спектр теоретичних та практичних проблем стосовно розвитку освіти дорослих в англомовних країнах (Н. Авшенюк, Т. Григор'єва, С. Коваленко), Польщі (О. Альперн, О. Сергєєва), Канаді (М. Борисова, М. Бусько, Л. Нос), Франції (О. Комар, В. Лащихіна, Ю. Несін), Німеччині (І. Сагун), США та Латиноамериканських країнах (О. Жижко, Н. Кутова, Н. Мукан, Н. Терьохіна, Н. Чаграк), скандинавських країнах (О. Огієнко, А. Роляк), Італійській республіці (Н. Постригач, О. Чеботарьова), Чехословаччині (Н. Дзюбишина, Н. Комарицька, Г. Товканець).

Предметом аналізу зарубіжних науковців виступав широкий спектр теоретичних та практичних проблем стосовно розвитку освіти у Словаччині. Загальні питання навчання та виховання, тенденції розвитку словацької системи шкільної освіти вивчали дослідники Е. Лукач, М. Махалова, Й. Музик, I. Пірогова, В. Фрк, та ін. Особлива увага дослідників зосереджена на системі підготовки професійних педагогічних кадрів та післядипломній педагогічній освіті у Словаччині. Грунтовний аналіз надбань словацької педагогіки у цьому напрямку подано у роботах I. Бернарікової, С. Лукач, О. Горак та ін.

Аналіз науково-педагогічної літератури й дисертаційних робіт дає підстави стверджувати, що проблема історії розвитку освіти дорослих у Словацькій республіці ще не стала предметом системного вивчення й спеціального аналізу вітчизняними вченими.

У даній статті ставимо за мету розкрити історичні передумови трансформації освіти дорослих у Словаччині, зокрема іiі сутність та динаміку розвитку у першій половині ХХ століття. 
Виклад основного матеріалу з обгрунтуванням отриманих наукових результатів. У цілому, сучасна теорія освіти дорослих у Словацькій республіці грунтується на доктрині американської системи освіти дорослих, яка відрізняється від загальноприйнятої у більшості європейських країн. У США освіта дорослих розглядається як процес, здійснюваний протягом життя, мета якого полягає у створенні умов для задоволення освітніх потреб дорослих, а також можливостей для їх подальшого професійного розвитку, самореалізації, підвищення ефективності та результативності їх життєдіяльності. При цьому, освіта дорослих передбачає врахування специфіки контингенту слухачів за віком, соціальною зрілістю, професійною спрямованістю, життєвим досвідом, мотивами навчання.

Такий підхід до системи освіти дорослих сформувався у Словацькій республіці у другій половині ХХ століття під впливом соціально-економічних умов, викликаних становленням Словаччини як суверенної, незалежної держави. Після 1990 року виникла необхідність конституювання та розвитку андрагогіки як галузі педагогічної науки, що охоплює теоретичні і практичні проблеми освіти, навчання i виховання дорослих. Історично так склалося, що увага словацьких педагогів була прикута не до формування теоретико-методологічного базису андрагогіки, а до практичних аспектів іiї функціонування у контексті освіти дорослих. Цей процес супроводжувався орієнтацію на інтегральну андрагогіку, в якій психологія та соціологія відіграють вирішальну роль [1]. У цьому контексті система освіти дорослих у Словацькій республіці має більш прикладний характер, аніж це можемо спостерігати в Україні. Причиною тому стала орієнтація на скандинавську систему освіти дорослих, тісно пов'язану 3 ім'ям данського вченого, філософа і педагога Н. Ф.С.Грундтвига. Скандинавські країни мають тривалі традиції та певні специфічні відмінності в системі освіти дорослих у порівнянні з іншими країнами, ефективність якої не викликає сумніву. Дослідник скандинавської системи освіти дорослих О. Огієнко вважає, що саме освітня концепція Н. Ф.С. Грундтвига (1783-1872) слугувала передумовою та основою для розвитку андрагогіки як науки у ХХ столітті [1: 39]. Ще у 1836 році Н.Ф.С. Грундтвиг запропонував створювати школи нового типу, т.зв. "народні університети" щось на зразок неформальних вечірніх шкіл та шкіл-лекторіїв для дорослих, які не мали достатньої освітньої підготовки, де популярно викладалися останні дані різних наук. Головний лозунг "народних університетів" Грундтвига - "Школа для життя!", тому уся концепція датського педагога будувалася на прагненні зрозуміти, які знання і вміння реально потрібні дорослим учням. Це не означало виключно прагматичну спрямованість шкіл Грундтвига (так, там вивчалися література і історія), - мова йшла про те, що ці знання повинні бути сприйняті людьми і служити загальному єдності. Грундтвигіанські школи були своєрідними громадами, де дозвілля та колективна праця були так само спільною справою викладачів та учнів, як і власне саме навчання [там само].

"Народні університети" набули небувалого поширення і в інших країнах, зокрема і у Словацькій республіці, територія якої у XIX столітті належала до Австро-угорської імперії. Важливим соціальним наслідком діяльності "народних університетів" для Словаччини було створення мережі сільських клубів для молоді, незалежних приватних та недільних шкіл, ідейним натхненником яких стала Матиця словацька (Matice slovenskej) - національний інститут словацької культури (заснований 1862 р.). Метою діяльності інституту було збереження та поширення народно-виховних традицій словаків, залучення дорослих до вирішення суспільних потреб народного господарства та культури.

Такий підхід до освіти дорослих на зламі тисячоліть був обумовлений значними соціальноекономічними змінами у розвитку більшості країн континентальної Свропи та США. Вітчизняний дослідник В. Тарасевич відмічає, що "саме у цей період відбувається поступовий перехід від системи вільного конкурентного ринку до недосконалих форм конкурентної боротьби. Така трансформація економіки стала закономірним результатом інтенсивного розвитку продуктивних сил, їхнього виходу на новий якісний рівень. У галузевій структурі економіки провідні позиції починає займати важка промисловість, в якій поступово формуються засади масового стандартизованого виробництва" [3: 45]. Ось чому у даний період небувалої гостроти набуває проблема ліквідації безграмотності та неосвіченості пересічних громадян, поширення серед них академічних знань, озброєння новими, економічного затребуваними, професійними уміннями та навичками. У такій ситуації виникає потреба у фахівцях, підготовлених до роботи з дорослим населенням. Інституціями, які ініціювали таку підготовку, стали народні школи, зокрема Вudeč на чолі з Карелом-Словомилом Амерлінгом (1807-1884). Він пропонував реформувати освіту з урахуванням розвитку науки та промисловості, ввести трудове навчання; як ідеальну мету пропагував всебічний і гармонійний розвиток особистості [4].

Цю мету було розвинуто у теорії професійної підготовки вчителів Густава Адольфа Лінднера (1828$1887)$ - першого чеського професора педагогіки, психології та етики Празького університету. Як просвітитель, він розумів, що без грунтовних педагогічних знань не можна серйозно говорити про навчання дорослих. Його освітнім ідеалом було сприяти одержанню знань усіма бажаючими не тільки у початковій школі, а й у вищих навчальних закладах. Педагог був переконаний: освіта має бути загальнодоступною, світською, побудованою на принципі народності. 
Такі ж позиції сповідував Людовит Велислав Штур (1815-1856), ідеолог словацького національного відродження XIX ст., ініціатор створення системи недільних шкіл двох рівнів:

- нижнього, спрямованого на забезпечення елементарної грамотності дорослого населення (формування навичок читання, письма та рахунку);

- вищого для дорослих, які мають елементарну освіту. Зміст навчання на цьому рівні складають 1) рактика вжитку рідної мови, 2) природознавство з елементам фізики, 3) історія Свропи та рідного краю, 4) зачатки правознавства, економіки та торгівлі, 5) трудове навчання та 6) усна народна творчість.

Організаційні засади недільних шкіл розроблено Йозефом Милославом Гурбаном (1817-1888) i представлено у роботі "Slovo о Spolkách Mjernosti a Školách Ned’elních". Педагог обгрунтував нову методику підготовки педагогічних кадрів, яка передбачала курсову підготовку усіх бажаючих пов'язати своє життя з учительством. Допомогу у цьому мали надавати представники просвітніх товариств у якості т.зв. "підучителів (podučitel'ov)" - помічників учителя. Їх зусилля були спрямовані на підготовку молодих учителів до виховання національної гідності та політехнічної освіти дорослих. До ідеологів політехнічної освіти дорослих належить Даніель Габріель Ліхард (1812-1882), визначальне місце у якій мав займати курс фізики, що надавав учням знання про науково-теоретичні основи промислового i сільськогосподарського виробництва. Одним із завдань навчання $\epsilon$ підготовка дорослого до професійного вибору на основі певних знань і навичок. Застосовуючи політехнічні знання на практиці, дорослі учні набувають практичних, загально трудових умінь та навичок, зокрема таких: користування простими знаряддями праці та інструментами, аналіз і часткове складання технічної документації, виконання нескладних операцій з ручної та механізованої обробки металу, дерева, ремонт нескладної апаратури та ін. Зміст професійної освіти забезпечує поглиблене вивчення наукових основ і технології обраного виду праці, формування спеціальних практичних умінь і навичок, виховання психологічних, моральних, естетичних якостей, необхідних фахівцеві конкретної галузі трудової діяльності. Реалізація змісту політехнічної освіти повинна допомогти дорослому визначити своє місце в житті, ефективно освоїти життєві та соціальні ролі.

Таким чином, засобами народних шкіл та університетів у XIX столітті забезпечувалася триєдина мета освіти дорослих:

- освітня мета - засвоєння академічних знань, подолання безграмотності, підвищення культурного рівня дорослих, розвиток їх освітніх звичок;

- виховна - формування високих моральних чеснот та благочестя, поваги до прав інших людей, національно спрямованого світогляду; організація дозвілля дорослих;

- політична - розвивати систему національної освіти.

Недільні школи Словаччини у другій половині XIX століття постали ефективною формою освіти дорослих селян, ремісників і робітників, які раніше не мали можливості вчитися. У рамках педагогічної діяльності шкіл формувалося розуміння цінності освіти: усвідомлювалася іiі значимість не тільки для соціуму, а й для окремої особистості, для розкриття ії внутрішнього духовного потенціалу. Можливість самореалізації та самоствердження, закладена в освіті, використовувалася недільними школами як потужний фактор соціалізації. Тому соціальне значення недільних шкіл полягало не в "окультурюванні" пересічного громадянина, а в конструюванні нової культури особистості та формуванні нових домінант масової свідомості.

Враховуючи зазначене, період другої половини XIX століття можемо окреслити як пропедевтичний у становленні системи освіти дорослих у Словацькій республіці. Він характеризується виділенням "дорослості" як соціально-психологічного феномену та розробкою педагогічної теорії освіти дорослих за зразком скандинавської наукової школи (Ю. Фандлі, С. Тешедік, П. Міхалко, Й. І. Байза та ін.).

Перша половина XX століття означена двома Світовими війнами, які обумовили соціальноекономічні та політичні умов формування Словаччини як держави. У результатів розпаду Австроугорської імперії 1918 року виникає Чехословацька республіка, як єдина держава чехів та словаків. Перед новою країною постали складні завдання розбудови суспільства, формування народного господарства та розвитку системи освіти. У зв'язку із чим виникає необхідність у спеціальних інституціях для дорослих (виникає Чехословацьке педагогічне товариство, відновлює свою діяльність Матиця словацька), мета діяльності яких полягала у формуванні нової генерації громадян, залучення іх до активної професійної діяльності у відповідності з особистими та суспільними потребами та нахилами, розвитку культурного світогляду пролетаря. Набуває подальшого розвитку ідея ціложиттєвого навчання, основи якої сформулював ще у XVII ст. Ян Амос Коменський у своїй праці "Panpaedia (Vševýchova)". Ця надихаюча, інноваційна ідея за часів видатного педагога не була реалізована в основному через те, що соціально-економічними умовами тієї епохи вона не була затребувана. Період Коменського - це період Просвіти, характерною ознакою культури якої $\epsilon$ ідеї гуманізму, у зв'язку з якими формується новий погляд на світ і людину. Гуманізм ставить у центр уваги людину, яка в ідеалі повинна бути життерадісною, сильною духом і тілом. Проголошувалась ідея гармонійного й багатостороннього розвитку особистості, що було притаманно ще античній педагогіці. Згодом ці ідеї у трансформованому 
вже вигляді набули актуальності у XX столітті. Під впливом соціально-економічних умов і факторів навчання протягом життя постає закономірністю. Зміни у характері та змісті праці, викликані науковотехнічною революцією, особливо інтелектуалізацією та змішуванням фізичної та розумової праці, комплексною механізацією, автоматизацією, комп'ютеризацією та інноваційністю робочих процесів, ескалацією та раціональним використанням вільного часу; широка участь громадян у суспільному управлінні; інформаційний вибух обумовлюють необхідність реалізації концепції ціложиттєвого навчання (celoživotné vzdelávanie).

Дана концепція здійснюється відповідно до чинних психологічних досліджень, якими встановлено, що людина здатна навчитися не тільки у молодому, але і у більш старшому віці. Уже на початку ХХ століття освіта протягом життя постає як необхідна активність людини будь-якого віку, що передбачає можливість не тільки оновити, змінити і використовувати раніше набуті знання і навички, але й розширювати свої розумові горизонти, підвищити культурний рівень, розвивати навички та позитивні риси особистості, набувати нового досвіду вже у новій спеціалізації. Така державна позиція була обумовлена економічною кризою, яка охопила Словаччину у $30-x$ роках і сприяла зростанню безробіття серед населення. У зв'язку із чим наказом Міністерства освіти та культури № 48.067/32 В від 7 червня 1932 р. було організовано курси для безробітних за двома напрямами:

а) загальне громадянське виховання, яке включало лекції (з урахуванням соціального статусу, культурних потреб та інтересів безробітних) із:

- соціально-економічних та соціально-політичних питань та прав працівників,

- конституції та державного управління,

- питань культури, освіти, літератури та охорони здоров'я та ін.

б) професійне навчання:

- мовні курси;

- стенограф, курси машинописного та бухгалтерського обліку;

- технічно орієнтовані курси (читання технічних малюнків, розрахунків, обслуговування машин);

- курси для безробітних жінок.

Щодо останніх, то вони тривали щонайменше 30 годин із систематичним навчанням принаймні 3 години на день, були адаптовані до місцевих умов, рівня освіти безробітних та конкретних потреб регіону.

Погіршення економічної ситуації, довготривале безробіття та падіння економічно найслабших регіонів призвели до того, що значна частина словаків емігрували на роботу до США та Канади. Тому проблема безробіття та, пов'язана 3 нею, проблема еміграції, стали одними 3 основних тем для обговорення на 3’їзді працівників народного виховання, проведеного 4-5 липня 1931 року в Зволені. Рішенням 3’їзду пропонувалося створити відділ консультування емігрантів, завданням якого було максимальне поширення інформації щодо особливостей переїзду в іншу країну, ііі культури, традицій, звичаїв, трудового законодавства та соціального захисту. Крім того, у межах своєї компетенції сприяти поверненню емігранта на батьківщину, перешкоджати шахрайським схемам залучення емігрантів ненадійними агенціями $з$ працевлаштування [4: 68].

Економічна криза вплинула і на фінансування освітньої галузі, культурних установ та організацій. Грошей катастрофічно не вистачало, через те пропонувалося передати повноваження навчання та виховання дорослих громадським організаціям, які фінансувалися із благодійних фондів. 3 цього приводу у суспільстві виникла гостра дискусія, яка закінчилася формуванням нового культурноосвітнього напряму діяльності словацького Союзу просвітництва, який включав розвиток театру, кіно-, радіо-, художнього мистецтва та ін.

Різноманітна і широка діяльність словацького Союзу просвітництва значною мірою сприяла тому, що вперше освіта почата реалізовуватись систематично, цілісно, постійним та досвідченим персоналом. У 30-ті роки ХХ століття було закладено основи наукових досліджень становлення та розвитку освіти дорослих у Словаччині. Зокрема, було видано ряд брошур, довідників, практичних посібників для освітніх діячів (наприклад, "Зручний довідник для освітніх працівників, "Десять років лялькарства у Словаччині" (довідник для лялькарів); історична брошура "Пам’ятник на честь святкування приходу чехословацької влади до Братислави"; "Як оздоровити наше село", "Міленіум святовацлавський 9291929"; "Скіоптікон та його обслуговування"; "Гроші та газдування ними", "Як писати книгу пам'яті муніципалітету"; "Народно-виховна робота на службі господарській майбутнього села"; "Довідник для працівника освіти", "Перелік словацьких книг, придатних для громадських бібліотек муніципалітетів"; "Теми розмов для народних бесід" та ін).

Певна річ, що події Другої світової війни негативно вплинули не тільки на суспільне життя словаків, а й на освітню та культурну сфери. Освіта дорослих відійшла на другий план, спершу - післявоєнна відбудова країни. I лише у 1965-1970 роках відбулось перше загальнодержавне дослідження фундаментального характеру "Система освіти та виховання дорослих" [6] (координатори: Ф. Хихлік, 
П. Пашка), результатом якого стало закладення наукових основ педагогіки дорослих та трьох ії підсистем: шкільного, позашкільного та корпоративного навчання дорослих.

Наукові основи педагогіки дорослих складають публікації та видання прикладного характеру 3 проблем професійної орієнтації, рекваліфікації та ціложиттєвого навчання дорослих, зокрема монографії П. Пашка, Ш. Пасіара, К. Шкоди, Й. Граца, Е. Лівечка, М. Тума, Й. Пергацса, наукові статті В. Швеца ті ін. Крім того, у 1972-1989 роках діяло Товариство професійного навчання та освіти дорослих (Edícia osvetoveho pracovníka), за сприянням якого було видано 22 монографії з проблем педагогіки дорослих (Ф. Хіхлік, К. Шкода, Ш. Пасіар, П. Пашка, В. Джува, Й. Пергацс, Г. Жаткуляк, В. Фабрі, КуклінковаЗагоршекова-Фішерова та ін.).

У цей же час виходить у світ "Педагогічна енциклопедія Словаччини", керівником якої був академік О. Павлік, котрий змобілізував науковий потенціал спеціалістів з педагогіки у Словаччині, створивши сприятливі умови для роботи групи дослідників (Й. Пергацс, Г. Жаткуляк, Я. Слобода, Т. Оллік, Ф.Карас, В. Фабі) під керівництвом П. Пашка та Ш. Пасіара. Результати їх досліджень були також представлені у спеціальних профільованих виданнях - "Просвітницька робота" (Osvetová práca) та "Новий шлях" (Nová cesta), спрямованих на розвиток теоретичної бази педагогіки дорослих.

Окрему групу видань становлять збірники за результатами науково-практичних конференцій 3 проблеми освіти дорослих, організовані Просвітницьким інститутом у Братиславі (Osvetový ústav v Bratislave) та Словацькою комісією з питань освіти та навчання Міністерства освіти Чехословаччини (1970-1989 рр.). Комісія працювала за наступними секціями:

- шкільного виховання та освіти дорослих (керівник Й. Пергацс);

- позашкільної освіти та виховання дорослих (керівник П. Пашка);

- корпоративної освіти та виховання дорослих (керівник В. Кестлер).

У цей час функціонували також Соціалістичної академії освіти, в рамках якої самостійно працювала Комісія з виховання та освіти дорослих (керівник Й. Пергацс) та громадські організації, об‘єднані у Народний фронт, зокрема Словацький червоний хрест, Словацький союз пасічників та ін., котрі орієнтувались на практичну реалізацію принципів педагогіки дорослих.

Завдячуючи такій плідній публіцистичній та практичній діяльності науковців, з 1978 року стала можливою підготовка фахівців зі спеціальності "Виховання та освіта дорослих", зокрема докторів наук в Університеті Коменського (Братислава) та спеціалістів у Прешівському університеті імені Павла Йозефа Шафаріка (Пряшів) на філософських факультетах.

Висновки та перспективи подальшого дослідження проблеми. Отже, система освіти дорослих першої половини XX століття у Словацькій республіці формувалася в умовах становлення іiї як суверенної, незалежної держави. Вказаний період характеризується практичною спрямованістю досліджень в галузі освіти дорослих у Словаччині (відбувається створення кафедр, науково-дослідних інститутів, професійних об'єднань, націлених на вдосконалювання процесу навчання загалом, і дорослих зокрема), обумовленої необхідністю підвищення професійного, культурного та загального рівня освіти працівників; поглиблення та розширення їх компетентностей та професійної переорієнтації.

До перспектив подальших досліджень відносимо аналіз провідних чинників розвитку освіти дорослих на початку XXI століття у Словацькій республіці.

\section{СПИСОК ВИКОРИСТАНИХ ДЖЕРЕЛ ТА ЛІТЕРАТУРИ}

1. Perhács Ján Personalizačné a socializačné aspekty rozvoja osobnosti dospelých / Ján Perhács. - 2. upr. vyd. Praha : Rozlet : Česká andragogická společnost, 2011. - 156 s. - (Česká a slovenská andragogika ; sv. 7) - ISBN 978-80-904824-4-9 (Rozlet).

2. Огієнко О. І. Філософська концепція освіти дорослих Н. Ф. С. Грундтвига / О. І. Огієнко // Проблеми та перспективи формування національної гуманітарно-технічної еліти. - Вип. 18 (22). - Харків : НТУ "ЧШ". 2008.

3. Історія економічних вчень : [підручник] / за ред. Тарасевича В. М., Петруні Ю. Є. - К. : "Центр учбової літератури", 2013. - 352 c.

4. Lukač E. Kapitoly z dejin výchovy a vydelávania dospelých / E. Lukač. - Prešov ; Prešovska univeryita v Prešove. Fakulta humanitných a prírodných vied, 2015. $-95 \mathrm{~s}$.

5. Lukáč M. Vybrané zásady individualizácie v druhošancovom vzdelávaní / M. Lukáč, L. Danielová, J. Schmied // Sborník z mezinárodní vědecké konference ICOLLE 2015. - Brno : Mendelova univerzita v Brně, 2015. - S. 336343.

6. Sústava výchovy a vzdelávania dospelých (záverecne studie z ukončenia štátnej vedecko-výskumnej úlohy zostavovatelia : P. Paska a E. Mala, vedecká oponentúra : jednotlivé štúdie boli oponované po etapach; komplexné dielo posúdil L. Bakoš). - Bratislava : OBZOR, 1972. - $420 \mathrm{~s}$.

\section{REFERENCES (TRANSLATED \& TRANSLITERATED)}

1. Perhács Ján Personalizačné a socializačné aspekty rozvoja osobnosti dospelých / Ján Perhács. - 2. upr. vyd. Praha : Rozlet : Česká andragogická společnost, 2011. - 156 s. - (Česká a slovenská andragogika ; sv. 7). ISBN 978-80-904824-4-9 (Rozlet). 
2. Ohiienko O. I. Filosofska kontseptsiia osvity doroslykh N. F. S. Hrundtvyha [Philosophical Concept of Adult Education by N.F.S. Grundtvig] / O. I. Ohiienko // Problemy ta perspektyvy formuvannia natsionalnoi humanitarno-tekhnichnoi elity" [Problems and Prospects of the Formation of the National Humanitarian and Technical Elite]. - Vyp. 18 (22). - Kharkiv : NTU "ChSh". - 2008.

3. Istoriia ekonomichnykh vchen [History of Economic Thought] : [pidruchnyk] / za red. Tarasevycha V. M., Petruni Yu. Ye. - K. : "Tsentr uchbovoi literatury", 2013. - $352 \mathrm{s.}$

4. Lukač E. Kapitoly z dejin výchovy a vydelávania dospelých / E. Lukač. - Prešov ; Prešovska univeryita v Prešove. Fakulta humanitných a prírodných vied, 2015. $-95 \mathrm{~s}$.

5. Lukáč M. Vybrané zásady individualizácie v druhošancovom vzdelávaní / M. Lukáč, L. Danielová, J. Schmied // Sborník z mezinárodní vědecké konference ICOLLE 2015. - Brno : Mendelova univerzita v Brně, 2015. - S. 336343.

6. Sústava výchovy a vzdelávania dospelých (záverecne studie z ukončenia štátnej vedecko-výskumnej úlohy zostavovatelia : P. Paska a E. Mala, vedecká oponentúra : jednotlivé štúdie boli oponované po etapach; komplexné dielo posúdil L. Bakoš). - Bratislava : OBZOR, 1972. - 420 s.

\section{Самойленко О. А. Становление системы образования взрослых в Словацкой республике в начале ХХ столетия.}

В статье представлены результаты теоретического анализа особенностей становления и развития

системы образования взросльх в Словацкой республике в начале ХХ века. Доказано возникновение 8 этот период необходимости повышения профессионального, культурного и общего уровня образования рабочих; углубление и расширение их компетенций и профессиональной переориентации. Раскрыта роль просветительских учреждений (народных школ и университетов, национального института словаикой культуры (Matice slovenskej) и др.) в формировании концепџии непрерывного обучения.

Ключевые слова: образование взрослых, народные школы и университеты, непрерывное обучение, просветительские организации.

\section{Samoilenko O. A. The Formation of the Adult Education System in the Slovak Republic at the Beginning of the XX Century.}

The process of socialization does not finish after the achievement certain age, it is continuous. Therefore, the education of adults in all historical periods was considered the most important socio-pedagogical function of society.

The overwhelming majority of European countries have normative acts on the legislative regulation of adult education, which defines its educational objectives, the principles and mechanisms of state support, the main subjects, their rights and responsibilities, etc. In this context, the Slovak Republic has its own solid experience.

The flagships of adult education at the beginning of the 20th century in Slovakia were the folk schools and universities, whose activities ensured the three goals of the adult education: education (assimilation of academic

knowledge, overcoming illiteracy, raising the cultural level of adults, developing their educational habits); educational (formation of high moral virtues and values, tolerance, nationally oriented outlook, organization of leisure for adults) and political (development of the system of national education).

The basic concept of adult education at the beginning of the 20th century was the very concept of lifelong learning, the purpose of which was not only to update, change and use previously acquired knowledge and skills, but also to expand the mental horizons of the individual, enhance the cultural level, develop skills and positive personality traits, acquire new experience in a new professional specialization.

Key words: adult education, popular schools and universities, lifelong learning, educational institutions. 